\title{
AMERICAN TELEMEDICINE ASSOCIATION: 20TH ANNUAL INTERNATIONAL MEETING \& TRADESHOW
}

\author{
JORDANA BERNARD
}



The 2015 American Telemedicine Association (ATA 2015) Annual International Meeting \& Tradeshow, will be held May 3-5, 2015 at the Los Angeles Convention Center. ATA 2015 will bring together healthcare professionals, leading telemedicine programs, and industry. This meeting has been the premier forum for professionals in the telemedicine, telehealth and mHealth space for over 20 years. The world-class, peer reviewed program will include over 500 educational sessions and posters, highlighting the latest innovations, applications and delivery models in telemedicine. The expansive exhibit hall will host hundreds of leading vendors with groundbreaking remote healthcare technologies and services. The educational sessions at ATA 2015 will offer training, information, and updates on issues vital to the practice and industry of telemedicine.

Detailed program information--including courses, sessions and Continuing Medical Education (CME) information--will be available at: http://www.americantelemed.org/ata-2015/conferenceoverview 
